\title{
The quality of sexual life after experiencing the episiotomy birth
}

\author{
Polona A. Mivšek, Petra Petročnik, Anita Jug Došler, Teja Škodič Zakšek \\ University of Ljubljana, Faculty of Health Sciences, Midwifery Department, \\ Zdravstvena pot 5, 1000 Ljubljana, Slovenia \\ polona.mivsek@zf.uni-lj.si
}

\begin{abstract}
Introduction: Episiotomy is a surgical cut of the perineum during childbirth to widen the pelvic outlet. The evidence shows women are less interested into sexual intercourse in the period after birth than they were before or during the pregnancy. This is the consequence of the changes in the postpartum period and often affected also by the perineal trauma. The purpose of literature review is to study the connection of perineal trauma on pain during sexual course in the postnatal period. Methods: Descriptive research method has been used, based on the review of relevant national and international literature on the scientific and professional level. The review of the literature took place in the January 2017, with the help of international databases. Searching terms included the following Key words: »episiotomy«, »sexuality«, "postpartum« and »dyspareunia«. The literature searching was limited on the Slovenian and English language and included the relevant papers published between 2007 and 2017. Results: The incidence of episiotomy in Slovenia is lower than $30 \%$ and varies between individual birth hospitals. The first episiotomy is a frequent reason resulting in women's fear of their first sexual intercourse, mostly the accompanied pain. Discussion and conclusions: The research shows that dyspareunia is more common in women having a vaginal birth, especially if the woman sustained a perineal rupture or episiotomy. Women usually return to their sexual life before the pregnancy after 6-12 months after birth. The quality of sexual life may be affected the whole year after childbirth.

Key words: sexuality, postpartum period, perineal trauma, genital pelvic pain
\end{abstract}


pisiotomy is a surgical incision into the perineum in order to assist the birth of a baby (Dahlen, 2015). The correct performance of the cut is of crucial meaning for the future sexual life of the labouring woman.

\section{Episiotomy}

The recommended use is restrictive (only in the case of indications such as foetal distress and the urgent need to finish the labour quickly) (Jiang et al., 2017). In case of the need for episiotomy, the correct timing to perform the procedure is when $3-4 \mathrm{~cm}$ of presenting part of the baby is visible in between the contractions. Local anaesthetic should be applied before the procedure (Dahlen, 2015). National Institute for Clinical Excellence - NICE (2017) suggests mediolateral type of episiotomy that must be executed in one clear cut. The recommended length of the incision is 2 and not more than $4 \mathrm{~cm}$. The cut should start at the midpoint of the fourchette, directed mediolateral at a $45-60^{\circ}$ angle, toward the ischial tuberosity (Kalis et al., 2017).

If the start of episiotomy is too lateral, Bartholin's glands can be damaged and if performed too soon, episiotomy can cause more bleeding (Holmes and Baker, 2006) and the musculus levator ani (Dahlen, 2015) that pays a major role in the woman's sexual excitation can be damaged. Episiotomy also weakens perineal muscles (Walsh, 2007) and can predispose woman to perineal trauma, therefore routines use is not advised (Jiang et al., 2017).

\section{Dyspareunia}

Dyspareunia is genital-pelvic pain, evoked by the penetration during the sexual intercourse and is classified as a sexual dysfunction by American Psychiatric Association - APA (2013). It can be expressed as a local pain at the vaginal introitus or a diffuse pain in the pelvis. The nature and intensity of pain varies. Dyspareunia can be primary or secondary and is closely connected to vaginismus and/or vulvodynia (Edwards and Bowen, 2010; World Health Organization - WHO, 2010).

The incidence of dyspareunia is increasing (APA, 2013), especially among young women. Systematic review by Latthe et al. (2006) showed that studies report very different rates of dyspareunia. Numbers in the reviewed studies varied from 8 to $21.8 \%$. Slovenian online study among women under the age of 30 $(\mathrm{N}=408)$ revealed prevalence of $15.4 \%$ (Kovačič, 2014).

The causes for dyspareunia can be physical or psychological (WHO, 2010). In the case of vulvo-vaginal pain are physical causes more common, especially common cause is perineal trauma (Edwards and Bowen, 2010). This can be closely connected with episiotomy. A very important determinant of postpartum sexual function is perineal pain and resultant dyspareunia (Škodič Zakšek, 2015).

Slovenian online study among 368 women who gave birth in the last 24 months and had episiotomy during it showed that women often postpone first 
sexual intercourse after the birth due to fear of pain ( $77 \%) .331$ of them reported lower sexual desire and among those, $45 \%$ of them identified pain as the most common cause (Grabner, 2015).

Therefore authors were interested in investigating the connection between dyspareunia and episiotomy after the childbirth.

\section{Methods}

Descriptive research method has been used, based on the review of relevant national and international scientific literature. The review of the literature took place in the January 2017, with the help of international databases.

Searching terms included the following key words: »episiotomy«, »sexuality«, "postpartum « and »dyspareunia«. The literature search was limited on the Slovenian and English language and included the relevant papers published between years 2007 and 2017. Later on the search was narrowed to the publications in the last five years in order to get the best and newest evidence.

The following databases were searched: CINAHL, Cochrane Library, EIFL Direct, MEDLINE, ScienceDirect, ProQuest, ERIC, Midirs and Embase.

We excluded studies of dyspareunia among women after different gynaecologic operations, with simultaneous mental health problems and studies among women with dyspareunia due to congenital malformations of reproductive organs. Excluded were also studies that investigated dyspareunia after the perineal lacerations, vacuum extraction, cesarean cestion or spontaneous delivery with intact perineum.

The search returned alltogether 77 references. Studies were sorted according to exclusion criteria. At the end 14 sources were included in the review (2 from CINAHL, 1 from Cochrane, 2 from EIFL Direct, 3 from Science direct and 6 from Springer).

\section{Results}

Sexual disfunctions are more common in postpartum year as in other periods of women's life (Abdool et al., 2009). Buurman \& Lagro-Janssen (2013) have found in their qualitative study $73 \%$ incidence of sexual disfunctions in the puerperium. Their sample was small and one could argue that their research design provide insufficient results. However also Rosen and Pukall (2016) and Khajehei et al. (2015) confirmed high incidence of problems in sexuality in the postpartum period. When comparing the incidence 3-, 6-, and 12- months postpartum it is obvious that the ratio of sexual dysfunctions decline in time after the childbirth (Khajehei et al., 2015).

In the case of perineal trauma Williams et al. (2007) found out that women experience in $54,5 \%$ sexual dysfunctions even after 12 months after the birth. Some authors (Doğan et al., 2017) report impact of the episiotomy on sexual desire, arousal and orgasm even 5 years after the birth. On contrary some stud- 
ies did not found differences in reasuming sexuality postnatally among women with episiotomy or those with intact perineum (Lagana et al., 2015; Kramna and Vrublova, 2016).

Dyspareunia is reported by $41 \%-67 \%$ of women 2 to 3 months postpartum in case of some kind perineal trauma quote Yeniel and Petri (2014). Acele and Karacam (2012) report even higher proportions of postnatal women with dyspareunia $-58,3 \%$. Necesalova et al. (2016) investigated diferrences in incidence of dyspareunia after mediolateral and lateral episiotomy. Women of both groups reported similar proportions of pain during sexual intercourse - 15,6\% in the group with mediolateral episiotomy and $16,1 \%$ in the group with lateral episiotomy.

The studies by Acele and Karacam (2012), Boran et al. (2013) and Sayasneh and Pandeva (2010) confirmed the results of older studies (Rogers et al., 2009; Klein et al., 2009) that episiotomy is more frequently connected to dyspareunia than ruptures of perineum. Statistically significant differences in the incidence of dyspareunia were found with higher age and presence of sexual problems already in the time of pregnancy (Acele and Karacam, 2012). Women with episiotomy in general have lower postpartum sexual function on FSF (Female Sexual Function) Index in comparison to those with no episiotomy (Lukas, 2014).

\section{Discussion}

Many postpartum changes may afect sexual health after the birth - even non-organic. One of those might be also the changes in the relationship after the arrival of the new family member (Simšič, 2009). Physical changes can affect sexuality indirectly (for example higher levels of oestogen or tiredness) (Acele and Karacam, 2012) or directly (like perineal trauma) (Luire et al., 2013). Dyspareunia can be also a result of incorrect perineal repair (Dahlen, 2015).

Women with perineal trauma tend to resume sexual activity later than women with intact perineum (McDonald and Brown, 2013). However women in general have decline of sexual life in the postpartum period, no matter what the mode of delivery was, claim Faisal-Cury et al. (2015) and women in general report dissatisfaction with the sexuality in the postnatal period (Khajehei et al., 2015).

When looking at the results of the studies that investigated the effect of episiotomy on the prevalence of dyspareunia in puerperium, the evidence are inconclusive. Further meta-synthesis should examine the differences in the proportions of dyspareunia among women with episiotomy, second degree lacerations or intact perineum.

\section{Conclusions}

Dyspareunia is one variable that may have a negative impact on women's lives and her partnership, especially if she cannot share her own sexual feelings and difficulties to her partner and health professionals. 
Through the article we have shown that episiotomy birth may affect woman's sexual life during the first year postpartum with more frequent pain, sexual dissatisfaction and decreased libido.

Perineal trauma affects women's physical, psychological and social wellbeing. This is the reason why clinicians, midwives and health care providers need knowledge and skills of sexual postpartum counselling, perinatal clinical care and treatment. They should be educated in order to counsel women regarding the potential postpartum sexual feelings and difficulties and to promote or improve the quality of their sexual functioning and relationship with partner.

\section{References}

ABDOOL, Z., THAKAR, R., SULTAN, A.H., 2009. Postpartum female sexual function. Eur J Obstet Gynecol Reprod Biol. Vol. 145, No. 2, pp.133-7.

ACELE, E.O., KARACAM, Z., 2012. Sexual problems in women during the first postpartum year and related conditions. J Clin Nurs. Vol. 21, No. 7-8, pp. 929-37.

APA, 2013. Diagnostic and statistical manual of mental disorders. 5 th ed. (DSM5). Arlington: American Psychiatric Publishing, pp. 437-40.

BORAN, S.U., CENGIZ, H., ERMAN, O., ERKAYA, S., 2013. Episiotomy and the Development of Postpartum Dyspareunia and Anal Incontinence in Nulliparous. Females Eurasian J Med, No. 45, pp.176-8o.

BUURMAN, M.B., JAGRO-JANSSEN, A.L., 2013. Women's perception of postpartum pelvic floor dysfunction and their help-seeking behaviour: a qualitative interview study. Scand J Caring Sci,. Vol. 27, No. 2, pp. 406-13.

DAHLEN, H., 2015 Perineal care and repair. In: PAIRMAN, S., PINCOMBE, J., Thorogood, C., TRACY, S., eds. Midwifery: preparation for practice. $3 \mathrm{rd}$ ed. Sydney: Churchill Livingstone, Elsevier, pp. 693-715.

DOĞAN B., GÜN, I., YILMAZ, A., MUHçU, M., 2017. Long-term impacts of vaginal birth with mediolateral episiotomy on sexual and pelvic dysfunction and perineal pain. J Matern Fetal Neonatal Med. Vol. 30, No. 4, pp. 457-46o.

EDWARDS, A., BOWEN, M.L., 2010. Dyspareunia. Pract Nurse. 39 (1):36-30.

FAISAL-CURY, A., MENEZES, P.R., QUAYLE, J., MATIJASEVICH, A., DINIZ, S.G., 2015. The relationship between mode of delivery and sexual health outcomes after childbirth. J Sex Med. Vol. 12, No. 5, pp. 1212-20.

GLOWACKA, M., ROSEN, N., CHORNEY, J., SNELGROVE CLARKE, E., GEORGE, R.B. (2014). Prevalence and Predictors of Genito-Pelvic Pain in Pregnancy and Postpartum: The Prospective Impact of Fear Avoidance. The Journal of Sexual Medicine. Vol. 11, No. 12, pp. 3021-34.

GRABNER, N., 2015. Spolnost po porodu $z$ epiziotomijo. Diplomsko delo. Ljubljana: Zdravstvena fakulteta. 
HOLMES, D., BAKER, P.N., 2006. Midwifery by ten teachers. London: Hodder Arnold, 2006.

JIANG, H., QIAN, X., CARROLI, G., GARNER, P., 2017. Selective versus routine use of episiotomy for vaginal birth. Cochrane Database of Systematic Reviews 2017, Issue 2. Art. No.: CDoooo81. DOI: 10.1002/14651858. CDoooo81.pub3

KALIS, V., RUSAVY; Z., PRKA, M., 2017. Episiotomy. In: DOUMOUCHTSIS, S., ed. Childbirth Trauma. 1sted. London: Springer-Verlag, pp.69-99.

KHAJEHEI, M., DOHERTY, M., TILLEY, P.J., SAUER, R., 2015. Prevalence and risk factors of sexual dysfunction in postpartum Australian women. J Sex Med. Vol. 12, No. 6, pp. 1415-26.

KLEIN, K., WORDA, C., LEIPOLD, H., GRUBER, C., HUSSLEIN, P., WENZL, R., 2009. Does the mode of delivery influence sexual function after childbirth? Journal of Womens Health No. 18, pp. 1227-1231.

KOVAČIČ, S., 2014. Disparevnija pri mladih ženskah do 3o. leta starosti: Diplomsko delo- Prešernova nagrada študentom. Ljubljana: Zdravstvena fakulteta.

KRAMNA, P., VRUBLOVA, Y., 2016. Episiotomy and women's sexual function 2-5 years after childbirth: A study from the Czech Republic. British Journal of Midwifery. Vol. 24, No. 12, pp. 870-876.

LAGANA, A.S., BURGIO, M.A., CIANCIMINO, L., SICILIA, A., MAGNO, C., BUTTICE, S., TRIOLO, O., 2015. Evaluation of recovery and quality of sexual activity in women during postpartum in relation to the different mode of delivery: a retrospective analysis. Minerva Ginecol. Vol. 67, No. 4, pp. 315-20.

LATTHE, P., LATTHE, M., SAY, L., GÜLMEZOGLU, M., KHAN, K.S., 2006. WHO systematic review of prevalence of chronic pelvic pain: a neglected reproductive health morbidity. BMC Public Health 6, p. 177.

LUIRE, S., AIZENBERG, M., BOAZ, M., KOVO, M., GOLAN, A., SADAN, O., 2013. Sexual function after childbirth by the mode of delivery: a prospective study. Arch Gynecol Obstet, Vol. 288, No. 4, pp. 785-92.

LUKAS, E., 2014. Primipara Undergoing Episiotomy had Lower Postpartum Sexual Function. INAJOG, Vol. 2, No. 2, pp. 91-95.

McDONALD, E.A., BROWN, S.J., 2013. Does method of birth make a difference to when women resume sex after childbirth? BJOG, Vol. 120, No. 7, pp.823-30.

NECESAlOVA, P., KARBANOVA, J, RUSAVY, Z., PASTOR, Z., JANSOVA, M., KALIS, V., 2016. Mediolateral versus lateral episiotomy and their effect on postpartum coital activity and dyspareunia rate 3 and 6 months postpartum. Sex Reprod Health, No. 8, pp. 25-30.

NICE, 2017. Intrapartum care for healthy babies and women. [viewed 12 June 2017]. Available from: https://www.nice.org.uk/guidance/cg19o 
ROGERS, R.G., BORDERS, N., LEEMAN, L.M., ALBERS, L.L., 2009. Does spontaneous genital tract trauma impact postpartum sexual function? Journal of Midwifery \& Womens Health. No. 54, pp. 98-103.

ROSEN, N.O., PUKALL, C., 2016. Comparing the Prevalence, Risk Factors, and Repercussions of Postpartum Genito-Pelvic Pain and Dyspareunia. Sexual Medicine Reviews, Vol. 4, No. 2, pp. 126-135.

SAYASNEH, A., PANDEVA, I., 2010. Postpartum sexual dysfunction: A literature review of risk factors and role of mode of delivery. BJMP. Vol. 3, No. 2, p. 316.

SIMŠIČ, B., 2009. Partnerski odnos pred, ob in po rojstvu prvega otroka. Diplomsko delo. Ljubljana: Zdravstvena fakulteta.

ŠKODIČ ZAKŠEK, T., 2015. Sexual Activity during Pregnancy in Childbirth and after Childbirth. In: MIVŠEK, A.P., ed. Sexology in midwifery. Rijeka: Intech, pp. 89-115.

YENIEL A.O., PETRI, E., 2014. Pregnancy, childbirth, and sexual function: perceptions and facts. International Urogynecology Journal, vol. 25, No. 1, pp. 5-14.

WALSH, D., 2007. Evidence-based care for normal labour and birth: a guide for midwives. London: Routledge.

WHO, 2010. International statistical classification of diseases and related health problems 1oth Revision (ICD-10). [viewed 12 June 2017]. Available from: http://apps.who.int/classifications/icd10/browse/2010/en

WILLIAMS, A., HERRON-MARKS, S., HICKS, C., 2007. The prevalence of enduring postnatal perineal morbidity and its relationship to perineal trauma. Midwifery No.3, pp.392-403. 